\title{
HUBUNGAN PENGALAMAN BERARSITEKTUR DENGAN KREATIVITAS DESAIN MAHASISWA
}

\author{
Elin Sekar Marlinda, M. Syaom Barliana, E. Krisnanto \\ Program Studi Pendidikan Arsitektur \\ Fakultas Pendidikan Teknologi dan Kejuruan \\ Universitas Pendidikan Indonesia \\ Jl. Dr. Setiabudhi 207 Bandung \\ email : elin_marlinda@yahoo.com
}

\begin{abstract}
Abstrak : Tujuan penelitian ini untuk mengetahui tingkat pengalaman berarsitektur, tingkat kreativitas desain, dan kontribusi pengalaman berarsitektur mahasiswa terhadap kreativitas desain arsitektur. Penelitian menggunakan metode deskriptif korelasional dengan pendekatan kuantitatif. Teknik pengumpulan data, untuk pengukuran variabel pengalaman berarsitektur, menggunakan teknik angket, sedangkan pengukuran variabel kreativitas desain memakai tes. Populasi adalah mahasiswa Program Studi Pendidikan Teknik Arsitektur, Universitas Pendidikan Indonesia (UPI). Hasil penelitian menunjukkan bahwa pengalaman berarsitektur mahasiswa termasuk dalam kategori cukup tinggi, sedangkan sedangkan kreativitas desain mahasiswa tergolong rendah. Uji hipotesis, memperlihatkan bahwa terdapat hubungan yang positif dan signifikan antara pengalaman berarsitektur mahasiswa dengan kreativitas desain arsitektur mahasiswa, dengan koefisien korelasi sebesar 0,66 yang termasuk kategori tinggi. Kontribusi pengalaman berasitektur terhadap kreativitas desain mahasiswa sebesar 43,76\%, sisanya ditentukan oleh faktor lain.
\end{abstract}

Kata kunci: kreativitas desain, pengalaman berarsitektur, pembelajaran berbasis pengalaman.

Abtract : The purpose of this research to determine the level of architecture experience, the level of design creativity, and contribution of the student architecture experience to design creativity. Descriptive correlational is research methods with quantitative approaches. Techniques of data collection, consisting of questionnaire techniques and the test. Population is a student of Architecture Education study program, Indonesia University of Education (UPI). The results showed that the architecture experience of students are included in the category is quite high, while the creativity of the design is low. Test the hypothesis, showing that there is a positive and significant relationship between architecture experience with architectural design creativity of students, with a correlation coefficient of 0.66 which includes the high category. Contribution to the architecture experience to creative design of students at $43.76 \%$, the rest is determined by other factors.

Key word: architecture experience, design creativity, experience based learning

\section{PENDAHULUAN}

Preseden arsitektur, merupakan salahsatu sumber inspirasi bagai kreativitas desain arsitektur bagi mahasiswa, bahkan bagi kalangan profesional arsitek sekalipun. Melalui upaya belajar dari sejarah, karya, peristiwa, dan pengalaman (ber)arsitektur, setiap perancang akan memperoleh perspektif yang lebih luas dan lebih dalam bagi kepentingan pemikiran dan ide desain. Tentu pada 
akhirnya, melalui proses belajar terus menerus, setiap perancang harus menemukan orisinilitas, otentisitas, dan karakter sendiri.

Proses perancangan arsitektur sendiri, pada dasarnya merupakan proses pengolahan gagasan untuk memecahkan masalah atau kasus pada suatu setting dan konteks lingkungan tertentu. Pengolahan ide dapat berjalan secara baik dan eksploratif, dengan modal kreativitas. Oleh sebab itu, proses perancangan arsitektur, membutuhkan kreativitas dalam merumuskan dan mengolah gagasan guna memecahkan persoalan yang ada.

Teori klasik dari Vitruvius (O’Gorman, 1998), secara sederhana, menyatakan arsitektur adalah disiplin ilmu yang mengintegrasikan fungsi (utilitas), teknologi (firmitas), dan estetika (venusitas). Disiplin ilmu yang berkaitan dengan estetika, tentu menuntut tingkat kreativitas tinggi dalam mengolah desain. Sekaitan dengan ini, khazanah pengetahuan yang luas akan membentuk stimulus pada kreativitas mahasiswa dalam mendesain. Pengetahuan tersebut dapat terbentuk, antara lain dari interaksi langsung antara mahasiswa dengan preseden arsitektur, khususnya melalui pengalaman ber-arsitektur.

Mahasiswa sebagai pembelajar orang dewasa, dituntut untuk dapat mengembangkan ilmu pengetahuan yang dipelajari, tanpa harus selalu bergantung dan dibatasi oleh materi yang diberikan oleh dosen dalam proses perkuliahan. Oleh karena itu, sudah seharusnya, mahasiswa arsitektur mengembangkan potensi dan kreativitas desain arsitektur, dengan cara menggali dan mengeksplorasi pengalaman berarsitekturnya.

Realitasnya, berdasarkan observasi pendahuluan, sebagian mahasiswa tidak memandang penting pengalaman berarsitektur di luar perkuliahan, guna menunjang kreativitas desain pada tugas mata kuliah. Sebagian mahasiswa masih beranggapan bahwa kesuksesan akademik perkuliahan cukup ditunjang dengan materi mata kuliah yang diberikan dosen.

Berdasarkan latar belakang itu, penelitian ini dilakukan dengan tujuan untuk mengetahui hubungan pengalaman berarsitektur mahasiswa terhadap proses kreativitas mahasiswa dalam mendesain arsitektur. Dengan demikian, penelitian ini mengukur tentang gambaran pengalaman berarsitektur mahasiswa, 
tingkat kreativitas desain mahasiswa, serta hubungan pengalaman berarsitektur terhadap kreativitas desain mahasiswa.

Atas dasar itu, pengalaman dipandang sebagai salahsatu sumber belajar untuk memperoleh pengetahuan dan kreativitas mahasiswa. Dalam konteks metode pembelajaran, dikenal Pembelajaran Berbasis Pengalaman (PBL), yaitu suatu proses untuk memperoleh pengetahuan yang diciptakan melalui berbagai pengalaman (Holzer and Andruet, 2000). Pengalaman ini menyangkut keseluruhan pengalaman intelektual, psiko-emosional, sosial, dan fisik-motorik.

PBL, menurut Boud, Cohen, and Andresen (1993), didasarkan asumsiasumsi sebagai berikut: pengalaman merupakan pondasi dari dan stimulus untuk belajar, pembelajaran merupakan proses yang holistik, belajar merupakan suatu konstruksi sosial dan kultural, belajar aktif dikonstruksi oleh pengalaman sendiri, belajar dipengaruhi oleh kondisi sosial-emosional.

PBL adalah sebuah metode yang dikondisikan secara sengaja oleh pendidik, yang menekankan pada dan berpusat pada pengalaman siswa. Namun demikian, dalam kaitan penelitian ini, pengalaman ber-arsitektur tersebut, lebih menunjuk kepada proses sengaja ataupun tidak sengaja yang dialami dan dieksplorasi mahasiswa sendiri, dan tidak dirancang oleh dosen.

Konteks ber-arsitektur, menunjukkan bahwa arsitektur bukan sekedar menyangkut produk jadi, tetapi merupakan sebuah proses. Klassen (1990), menyatakan bahwa berarsitektur adalah sebuah proses kontemplasi, yang terjadi pada setiap tahap: memahami arsitektur (understanding architecture); mengalami arsitektur (experiencing architecture); membuat arsitektur (making architecture). Sementara itu, Salura (2001), mengidentifikasi empat kegiatan yang saling terkait, yaitu membuat, menggunakan, mengalami, dan memahami arsitektur. Empat kegiatan ini tidak harus selalu berjalan berurutan secara linier, tetapi bisa tumpang tindih satu sama lain, serempak, atau siklus ulang.

Pada mulanya, adalah sederhana. Manusia membuat shelter untuk memenuhi kebutuhan akan perlindungan fisik, sebagai respon terhadap kondisi lingkungannya. Kemudian, fungsi bangunan bertambah kompleks, sesuai dengan perkembangan pemikiran, pemahaman, dan budaya. Fungsi, dengan demikian, tidak lagi sekedar menyangkut perlindungan fisik dan keamanan, tetapi juga 
mewadahi aktivitas, kenyamanan, interaksi sosial, identifikasi simbolik, dan lainlain.

Perkembangan pemikiran dan pemahaman manusia atas lingkungan buatan, diperoleh melalui pengalaman langsung dalam menggunakan bangunan, interaksi langsung dengan ruang, melalui kepekaan panca indera. Demikianlah, perilaku membuat, menggunakan, mengalami, memahami arsitektur, menjadi suatu ritus dalam interaksi manusia dengan lingkungan buatannya secara terus menerus.

Akan halnya Arsitek, berperan dalam proses membuat arsitektur, melalui prosedur perancangan untuk menjawab permasalahan dan kebutuhan pemakai, dan kemudian mengimplementasikannya dalam bentukan lingkungan buatan. Dalam proses desain itu, Arsitek biasanya menggunakan imajinasinya, untuk menggali pengalaman saat berdialog dengan ruang. Pengalaman ini didapatkan saat ia menggunakan produk arsitektur secara langsung, sehingga diperoleh pemahaman tentang apa dan bagaimana bentukan ruang yang diharapkan sesuai dengan kebutuhan pemakai.

Dalam analogi yang sama, mahasiswa sebagai pembelajar, juga dapat mengikuti ritus membuat, menggunakan, mengalami, dan memahami arsitektur, dalam rangka meningkatkan kreativitas desainnya. Meskipun demikian, fokus penelitian ini hanya mencakup kegiatan menggunakan, mengalami, dan memahami arsitektur. Soalnya, mahasiswa umumnya baru terlibat pada proses perancangan, dan belum sampai mewujudkan desain dalam bangunan yang nyata serta fungsional.

Kreativitas, merupakan faktor sangat penting dalam proses desain arsitektur. Karena itu, kreativitas perlu terus digali dan ditumbuhkan sangat dibutuhkan dalam penyusunan desain arsitektur. Proses kreatif ini yang membuat suatu karya arsitektur seseorang berbeda dengan karya orang lain. Kreativitas dalam ber-arsitektur dapat ditinjau dari teknik kreativitas itu sendiri, atau dari mana kreativitas muncul sehingga seorang arsitek dapat mengembangkan kreativitasnya. 
Kreatifitas, menurut Antoniades (1992), merupakan proses akhir imajinasi, yaitu suatu perubahan dari dari tahap konsep ke tahap realisasi. Imajinasi berada dalam alam pikiran, sedangkan kreatifitas berada pada alam membuat. Kreatifitas ini dapat dipicu oleh hal yang bersifat tangible (yang teraga, dapat dinyatakan) dan intangible (yang tak teraga, tak dapat dinyatakan).

Kreativitas, menurut Kowaltowski dkk (2010), merupakan suatu proses menjadi sensitif terhadap permasalahan, mengidentifikasi, menyusun hipotesis, menemukan solusi, dan kemudian menguji serta mengkomunikasikannya kepada khalayak yang lebih luas. Hal ini sejalan dengan kriteria kreativitas menurut Danny dan Davies (1982), yang mencakup: Sensitivity problems, artinya kepekaan terhadap masalah yang muncul; Originality, artinya pemecahan masalah dengan cara baru, bukan meniru pemecahan masalah yang lain; Ingenuity, artinya kecerdikan dalam pemecahan masalah; Breadth, artinya ketepatan dalam pemecahan masalah dan berguna; Recognity by peers, artinya ada pengakuan dari kelompok bidang keahlian terhadap inovasinya.

Demikianlah, dapat disimpulkan bahwa menghasilkan sesuatu yang baru adalah aspek penting dalam kreativitas. Kepekaan serta pola pikir lateral, divergen, dan berbeda dengan cara pikir individu pada umumnya, merupakan modal dasar untuk menghasilkan suatu produk kreatif arsitektural yang memiliki nilai orisinilitas. Namun demikian, desain yang orisinil tidak semata-mata merupakan produk yang harus baru atau belum pernah tercipta sama sekali sebelumnya. Orisinalitas desain arsitektur, dapat dilihat dari konsep pengolahan yang khas dan unik, meskipun produk yang dihasilkan memiliki kesamaan fungsi atau bentukan yang mirip dengan produk arsitektur yang pernah ada.

\section{METODE}

Penelitian ini menggunakan metode deskriptif-korelasional dengan pendekatan kuantitatif. Teknik pengumpulan data, untuk pengukuran variabel pengalaman berarsitektur, menggunakan teknik angket, menggunakan skala Likert, serta sudah diuji validilitas dan reliabilitasnya. Pengukuran variabel kreativitas desain memakai tes, dengan pengujian validitas oleh expert judgment yaitu tiga dosen mata kuliah Perancangan Arsitektur. 
Populasi adalah mahasiswa Program Studi Pendidikan Teknik Arsitektur, Universitas Pendidikan Indonesia (UPI), dengan teknik sampling purposif. Pertimbangannya, mahasiswa minimal sudah menempuh semester enam, sehingga dianggap sudah cukup memiliki pengalaman beraksitektur, dan sudah mempelajari dasar-dasar kaidah kreativitas desain pada mata kuliah sebelumnya. Atas dasar itu, dipilih, mahasiswa yang mengontrak mata kuliah Studio Perancangan Arsitektur tiga (SPA III) tahun ajaran 2012. Keseluruhan jumlah sampel mahasiswa adalah 62 orang

Tabel 1. Indikator Penelitian

\begin{tabular}{|c|c|}
\hline Aspek & Indikator \\
\hline $\begin{array}{l}\text { Pengalaman } \\
\text { arsitektur } \\
\text { Mahasiswa }\end{array}$ & $\begin{array}{l}\text { 1. Menggunakan Arsitektur } \\
\text { a. Mengoperasikan objek arsitektur } \\
\text { b. Menggunakan produk arsitektur sesuai fungsi awal } \\
\text { dibuatnya produk tersebut } \\
\text { 2. Mengalami Arsitektur } \\
\text { a. Merasakan dengan panca indera mengenai keseluruhan } \\
\text { objek arsitektur } \\
\text { b. Interaksi langsung dengan ruang / objek arsitektur } \\
\text { 3. Memahami Arsitektur } \\
\text { a. Mampu menerjemahkan pengalaman langsung dengan } \\
\text { objek arsitektur menjadi atau dalam suatu konsep } \\
\text { b. Mampu menjelaskan pemecahan masalah pada arsitektur } \\
\text { c. Mengetahui konsep untuk membuat desain arsitektur }\end{array}$ \\
\hline $\begin{array}{l}\text { Kreativitas Desain } \\
\text { Mahasiswa }\end{array}$ & $\begin{array}{l}\text { 1. Kepekaan terhadap masalah yang muncul } \\
\text { 2. Originalitas dan keunikan ide desain } \\
\text { 3. Kecerdikan dalam pemecahan masalah } \\
\text { 4. Ketepatan pemecahan masalah dan mengandung nilai guna }\end{array}$ \\
\hline
\end{tabular}

Dengan sampel purposif, serta hasil pengujian normalitas yang menunjukkan data tidak berdistribusi normal, maka analisis data menggunakan statistik non parametrik. Teknik analisis data deskriptif menggunakan analisis statistik deskriptif (frekuensi, mean, standar deviasi). Pengujian hipotesis, menggunakan analisis korelasi Spearman.

Interpretasi data deskriptif, didasarkan kepada parameter sebagai berikut.

1. Perhitungan nilai rata-rata ideal (Mi) dan standar deviasi ideal (SDi): a. Nilai rata-rata ideal $(\mathrm{Mi})=1 / 2$ (nilai ideal max.+ nilai ideal min.); b. standar deviasi ideal $(\mathrm{SDi})=1 / 6($ nilai ideal max.- nilai ideal min. $)$ 
2. Batasan-batasan Kategori: a. Sangat Rendah $=\mathrm{X}<\mathrm{Mi}-2 \mathrm{SDi} ; \mathrm{b}$. Rendah $=$ Mi-1SDi $>X \geq$ Mi-2SDi; c. Cukup $=$ Mi +1 SDi $>X \geq$ Mi-1SDi ; d. Tinggi $=$ $\mathrm{Mi}+2 \mathrm{SDi}>\mathrm{X} \geq \mathrm{Mi}+1 \mathrm{~S}$; e. Sangat Tinggi $=\mathrm{X} \geq \mathrm{Mi}+2 \mathrm{SDi}$

3. Kriteria Tabel 2koefisien korelasi, dijelaskan pada tabel berikut.

Tabel 2. Kriteria koefisien korelasi

\begin{tabular}{ll}
\hline \multicolumn{1}{c}{ Koefisien Korelasi } & \multicolumn{1}{c}{ Makna Koefisien Korelasi } \\
\hline $\mathrm{r}=-1$ & Korelasi negatif sempurna \\
$-1<\mathrm{r} \leq-0,80$ & Korelasi negatif tinggi sekali \\
$-0,80<\mathrm{r} \leq-0,60$ & Korelasi negatif tinggi \\
$-0,60<\mathrm{r} \leq-0,40$ & Korelasi negatif sedang \\
$-0,40<\mathrm{r} \leq-0,20$ & Korelasi negatif rendah \\
$-0,20<\mathrm{r} \leq 0$ & Korelasi negatif rendah sekali \\
$\mathrm{r}=0$ & Tidak mempunyai korelasi linier \\
$0<\mathrm{r}<0,20$ & Korelasi rendah sekali \\
$0,20 \leq \mathrm{r}<0,40$ & Korelasi rendah \\
$0,40 \leq \mathrm{r}<0,60$ & Korelasi sedang \\
$0,60 \leq \mathrm{r}<0,80$ & Korelasi tinggi \\
$0,80 \leq \mathrm{r}<1$ & Korelasi tinggi sekali \\
$\mathrm{r}=1$ & Korelasi sempurna \\
\hline
\end{tabular}

Sumber: Saputra (2007)

\section{HASIL PENELITIAN}

Hasil penelitian deskriptif, menunjukkan bahwa tingkat pengalaman berarsitektur mahasiswa (variabel X) dapat diinterpretasikan sebagai berikut. Pertama, Perhitungan nilai rata-rata ideal (Mi) dan standar deviasi ideal (SDi): a. Nilai rata-rata ideal $(\mathrm{Mi})=1 / 2(144+36)=90 ;$ b.Standar deviasi ideal $(\mathrm{SDi})=1 / 6$ $(144-36)=18$. Kedua, batasan-batasan Kategori: a. Sangat Rendah $=\mathrm{X}<\mathrm{Mi}-2$ $\mathrm{SDi}=\mathrm{X}<54$; b. Rendah $=\mathrm{Mi}-1 \mathrm{SDi}>\mathrm{X} \geq \mathrm{Mi}-2 \mathrm{SDi}=72>\mathrm{X} \geq 54$; c. Cukup $=\mathrm{Mi}$ $+1 \mathrm{SDi}>\mathrm{X} \geq \mathrm{Mi}-1 \mathrm{SDi}=108>\mathrm{X} \geq 72$; d. Tinggi $=\mathrm{Mi}+2 \mathrm{SDi}>\mathrm{X} \geq \mathrm{Mi}+1 \mathrm{SDi}=$ $126>X \geq 108$; e. Sangat Tinggi $=X \geq M i+2$ SDi $=X \geq 126$.

Tabel 3. Tabel Interpretasi Variabel X

\begin{tabular}{lccc}
\hline \multicolumn{1}{c}{ Kategori } & Rentang & Frekuensi & Persentase \\
\hline Sangat Rendah & $\mathrm{X}<54$ & 0 & $0.00 \%$ \\
Rendah & $72>\mathrm{X} \geq 54$ & 2 & $3.23 \%$ \\
Cukup & $108>\mathrm{X} \geq 72$ & 49 & $79.03 \%$ \\
Tinggi & $126>\mathrm{X} \geq 108$ & 10 & $16.13 \%$ \\
Sangat Tinggi & $\mathrm{X} \geq 126$ & 1 & $1.61 \%$ \\
\hline Total & & 62 & $100.00 \%$ \\
\hline
\end{tabular}

Data menunjukkan bahwa tidak terdapat mahasiswa yang memiliki pengalaman berarsitektur sangat rendah, sedangkan kategori rendah mencapai 
$3,23 \%$, kategori cukup 79,03\%, kategori tinggi 16,13\%, dan kategori sangat tinggi 1,61\%. Dari hasil perhitungan rerata (Mean) diperoleh nilai 97, dan berada pada interval $108>\mathrm{X} \geq 72$. Dengan demikian dapat disimpulkan, bahwa rata-rata pengalaman berarsitektur mahasiswa dalam penelitian ini tergolong cukup.

Pengalaman berarsitektur mahasiswa mencakup tiga aspek yang digunakan sebagai tolak ukur kegiatan berarsitektur yang pernah dialami oleh mahasiswa. Berikut disajikan tabel interpretasi data dari aspek-aspek dalam pengalaman berarsitektur mahasiswa.

Tabel 4. Tabel Interpretasi Aspek Variabel X

\begin{tabular}{clccc}
\hline No & Aspek Yang Diteliti & $\mathbf{\Sigma X}$ & Skor Ideal & Skor \\
\hline 1 & Menggunakan & 1912 & 3472 & $55.07 \%$ \\
2 & Mengalami & 2595 & 3720 & $69.76 \%$ \\
3 & Memahami & 1508 & 2232 & $67.56 \%$ \\
\hline \multicolumn{2}{c}{ Jumlah } & $\mathbf{6 0 1 5}$ & $\mathbf{9 4 2 4}$ & \\
\hline & Rata-rata & $\mathbf{6 4 \%}$ & $\mathbf{1 0 0 \%}$ & \\
\hline
\end{tabular}

Berdasarkan perolehan total persentase diatas, dapat diterjemahkan ke dalam rentang berikut ini,

\begin{tabular}{|c|c|c|c|c|}
\hline $\begin{array}{l}\text { Sangat } \\
\text { Rendah }\end{array}$ & Rendah & Cukup & Tinggi & $\begin{array}{l}\text { Sangat } \\
\text { Tinggi }\end{array}$ \\
\hline 2232 & 4030 & $5828 \quad 6015$ & 7626 & 9424 \\
\hline
\end{tabular}

Perolehan rata-rata pengalaman berarsitektur mahasiswa, adalah $64 \%$ total nilai ideal yang diharapkan dengan nilai 6015. Jika dilihat pada rentang kategori, nilai tersebut berada pada interval "cukup dan tinggi", tetapi lebih mendekati kategori cukup. Maka dapat disimpulkan pengalaman berarsitektur mahasiswa termasuk kategori cukup.

Uraian per aspek pengalaman berarsitektur mahasiswa, memperlihatkan bahwa aspek 'mengalami' memiliki persentase tertinggi sebesar $69.76 \%$ dari total nilai ideal yang diharapkan, sedangkan persentase terkecil yaitu sebesar $55.07 \%$ terdapat pada aspek 'menggunakan'. Aspek 'memahami' memiliki persentase sebesar $67,56 \%$. 
Selanjutnya, hasil penelitian mengenai kreativitas desain mahasiswa (variabel Y), dapat dinterpretasikan sebagai berikut. Pertama, perhitungan nilai rata-rata ideal (Mi) dan standar deviasi ideal (SDi): a. Nilai rata-rata ideal (Mi) $=1 / 2(48+12)=30 ;$ b. Standar deviasi ideal $(\mathrm{SDi})=1 / 6(48-12)=6$. Kedua, batasan-batasan kategori: a. Sangat Rendah $=\mathrm{X}<\mathrm{Mi}-2 \mathrm{SDi}=\mathrm{X}<18$; b. Rendah $=\mathrm{Mi}-1 \mathrm{SDi}>\mathrm{X} \geq \mathrm{Mi}-2 \mathrm{SDi}=24>\mathrm{X} \geq 18$; c. Cukup $=\mathrm{Mi}+1 \mathrm{SDi}>\mathrm{X} \geq \mathrm{Mi}-1 \mathrm{SDi}=$ $36>\mathrm{X} \geq 24$; d. Tinggi $=\mathrm{Mi}+2 \mathrm{SDi}>\mathrm{X} \geq \mathrm{Mi}+1 \mathrm{SDi}=42>\mathrm{X} \geq 36$; e. Sangat Tinggi $=\mathrm{X} \geq \mathrm{Mi}+2 \mathrm{SDi}=\mathrm{X} \geq 42$

Tabel 5. Tabel Interpretasi Variabel Y

\begin{tabular}{|c|c|c|c|}
\hline Kategori & Rentang & Frekuensi & Persentase \\
\hline Sangat Rendah & $X<18$ & 7 & $11.29 \%$ \\
\hline Rendah & $24>X \geq 18$ & 27 & $43.55 \%$ \\
\hline Cukup & $36>x \geq 24$ & 28 & $45.16 \%$ \\
\hline Tinggi & $42>X \geq 36$ & 0 & $0.00 \%$ \\
\hline Sangat Tinggi & $X \geq 42$ & 0 & $0.00 \%$ \\
\hline \multicolumn{2}{|c|}{ Total } & 62 & $100.00 \%$ \\
\hline
\end{tabular}

Data menunjukkan bahwa bahwa tidak terdapat mahasiswa yang memiliki kreativitas desain tergolong tinggi dan sangat tinggi, sedangkan kategori sangat rendah mencapai 11,29\%, kategori rendah 43,55\%, dan kategori cukup 45,16\%. Dari hasil perhitungan rata-rata (Mean) didapat nilai 22,8, yang berada pada interval $24>X \geq 18$. Dengan demikian dapat disimpulkan, bahwa rata-rata kreativitas desain mahasiswa dalam penelitian ini tergolong rendah.

Dalam penilaian kreativitas desain arsitektur, terdapat empat aspek yang ditinjau untuk menilai seberapa jauh produk desain yang dihasilkan bernilai kreatif. Berikut disajikan, interpretasi dari keempat aspek yang menjadi tolak ukur kreativitas desain mahasiswa,

Tabel 6. Tabel Interpretasi Aspek Variabel Y

\begin{tabular}{|c|c|c|c|c|}
\hline No & Aspek Yang Diteliti & $\Sigma \mathbf{X}$ & $\begin{array}{l}\text { Skor } \\
\text { Ideal }\end{array}$ & Skor \\
\hline 1 & Kepekaan terhadap masalah yang muncul & 367 & 744 & $49,33 \%$ \\
\hline 2 & Originalitas dan keunikan ide desain & 383 & 744 & $51,48 \%$ \\
\hline 3 & Kecerdikan dalam pemecahan masalah & 330 & 744 & $44,35 \%$ \\
\hline 4 & $\begin{array}{l}\text { Ketepatan pemecahan masalah yang mengandung nilai } \\
\text { guna }\end{array}$ & 337 & 744 & $45,30 \%$ \\
\hline \multicolumn{2}{|r|}{ Jumlah } & 1417 & 2976 & \\
\hline \multicolumn{2}{|r|}{ Rata-rata } & $48 \%$ & $100 \%$ & \\
\hline
\end{tabular}


Dari perolehan total persentase diatas, dapat diterjemahkan ke dalam rentang berikut ini,

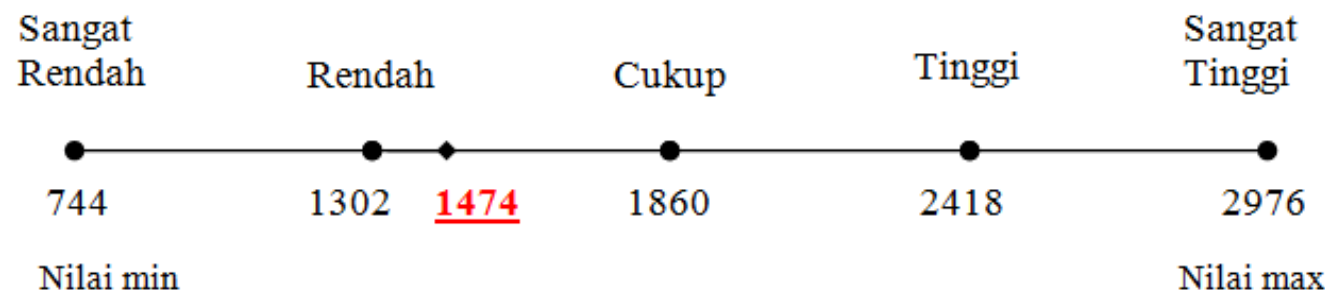

Perolehan rata-rata kreativitas desain mahasiswa adalah $48 \%$ dari total nilai ideal yang diharapkan, dengan nilai 1417. Jika dilihat pada rentang kategori, nilai tersebut berada pada interval "rendah dan cukup", tetapi lebih mendekati kategori rendah. Maka dapat disimpulkan kreativitas desain mahasiswa termasuk kategori rendah.

Perolehan keempat aspek penilaian kreativitas desain arsitektur diatas memiliki selisih nilai yang kecil, artinya hampir tidak ada perbedaan. Aspek orisinalitas dan keunikan ide desain memiliki skor yang paling tinggi dibandingkan dengan ketiga aspek lainnya. Persentase yang diperoleh yaitu sebesar $51,48 \%$. Skor terendah terdapat pada aspek kecerdikan dalam pemecahan masalah dengan nilai persentase sebesar $44,35 \%$.

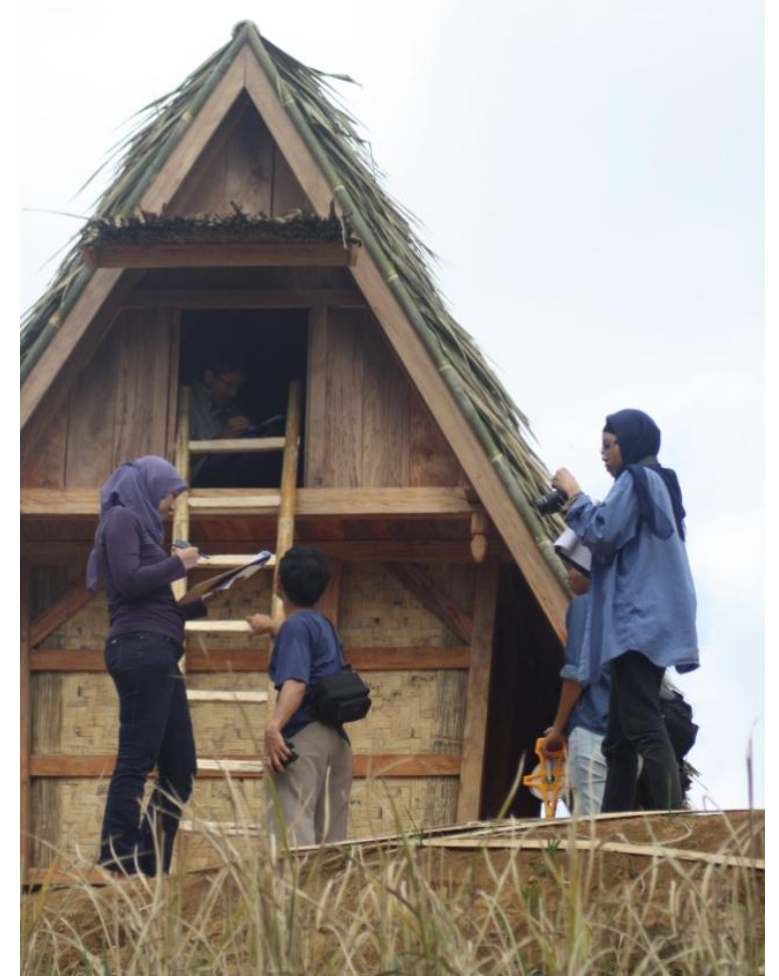

Gambar 1. Pengalaman berarsitektur: Observasi lapangan di kampung adat Cipta Gelar, Sukabumi 
Selanjutnya, hasil perhitungan korelasi dengan analisis korelasi Rank Spearman, diperoleh harga koefisien korelasi $(\rho)$ sebesar 0,66. Harga koefisien korelasi tersebut dikonsultasikan pada kriteria penafsiran pada Tabel 2, dan menunjukkan hubungan antara variabel $\mathrm{X}$ (pengalaman beraksitektur) dengan $\mathrm{Y}$ (kreativitas desain) tergolong pada korelasi positif yang tinggi.

Tabel 7. Distribusi Uji Hipotesis

\begin{tabular}{cccc}
\hline$\rho$ & $\mathbf{t}_{\text {hitung }}$ & $\mathbf{t}_{\text {tabel }}$ & $\mathrm{KD}$ \\
\hline 0,66 & $\mathbf{6 , 8 3}$ & $\mathbf{1 , 6 7}$ & 43,76 \\
\hline
\end{tabular}

Keterangan :

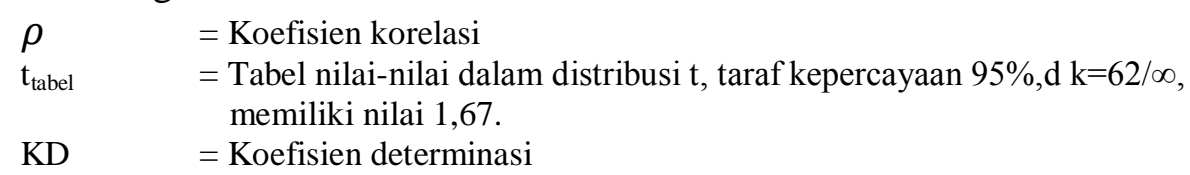

Uji signifikansi dihitung menggunakan rumus signifikansi koefisien korelasi, dengan $n=62$ dan $\rho=0,66$, dan didapatkan nilai $t_{\text {hitung }}$ sebesar 6,83 . Nilai $\mathrm{t}_{\text {hitung }}$ ini dikonsultasikan pada tabel nilai-nilai dalam distribusi $\mathrm{t}$, dengan taraf kepercayaan $(\mathrm{tk})=95 \%$ dan pada $\mathrm{dk}=62-2=60$, maka didapat $\mathrm{t}_{\text {tabel }}$ sebesar 1,66. Kriteria penafsiran: Jika $t_{\text {hitung }}>t_{\text {tabel }}$, maka $\mathrm{H} 0$ ditolak dan $\mathrm{H}_{\mathrm{a}}$ diterima; Jika $\mathrm{t}_{\text {tabel }}$ $<\mathrm{t}_{\text {hitung }}$ maka $\mathrm{H} 0$ diterima dan $\mathrm{H}_{\mathrm{a}}$ ditolak.

Hasil analisis menunjukan bahwa $t_{\text {hitung }}$ lebih besar dari $t_{\text {tabel }}\left(t_{\text {hitung }}>\right.$ $\mathrm{t}_{\text {tabel }}$ ), yaitu 6,83>1,67, maka dapat disimpulkan bahwa hipotesis alternatif (Ha) penelitian diterima dan Hipotesis no (Ho) ditolak. Dengan demikian, "Terdapat hubungan yang positif dan signifikan antara pengalaman berarsitektur dengan kreativitas desain mahasiswa." Hubungan ini ditunjukkan dengan nilai korelasi sebesar 0,67 yang termasuk kedalam kategori tinggi.

Untuk mengetahui besarnya kontribusi variabel $\mathrm{X}$ terhadap variabel $\mathrm{Y}$, dapat dihitung dengan menggunakan rumus koefisien determinasi (KD), sebagai berikut : KD $=r^{2} \times 100 \%=(0,67)^{2} \times 100 \%=43,76 \%$. Dari hasil perhitungan tersebut, dapat disimpulkan bahwa pengalaman berarsitektur mahasiswa (variabel $\mathrm{X}$ ) berkontribusi terhadap kreativitas desain mahasiswa (variabel Y) sebesar 43,76\%. Artinya kreativitas desain mahasiswa sebesar $43,76 \%$ turut ditentukan oleh pengalaman berarsitektur mahasiswa, sedangkan 
sisanya, yaitu sebesar 56,24\% disumbangkan oleh hal-hal lain yang tidak diteliti dalam penelitian ini.

\section{PEMBAHASAN}

Hasil penelitian menunjukkan bahwa tingkat pengalaman berarsitektur mahasiswa tergolong cukup. Cukup, artinya tergolong rata-rata saja (mediocre). Ini dapat ditafsirkan, bahwa mahasiswa program studo Pendidkan Arsitektur UPI sebagai responden yang telah menempuh masa kuliah selama tiga tahun, berinteraksi dengan objek arsitektur tidak terlalu intens.

Pengalaman berarsitektur, baik melalui tugas formal dan terstruktur dari dosen, maupun pengalaman informal mahasiswa, tampaknya belum menjadi kebutuhan yang sangat tinggi bagi mahasiswa. Berbagai kegiatan berarsitektur, seperti praktek kerja industri, kuliah kerja lapangan, observasi arsitektur dan lingkungan, ziarah arsitektur, maupun dalam interaksi keseharian mahasiswa dengan produk arsitektur, belum menjadi kegiatan yang eksploratif

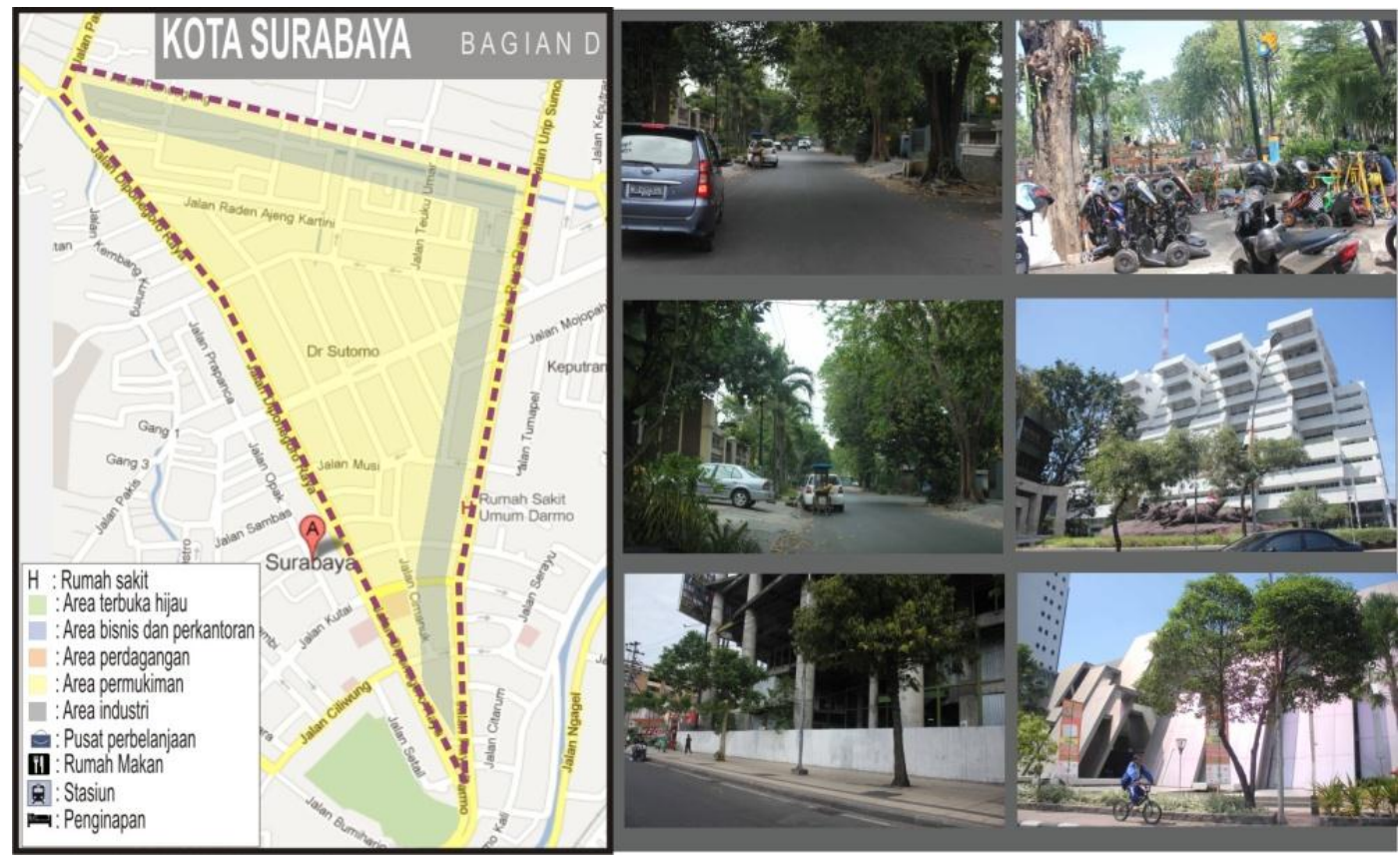

Gambar 2. Pengalaman berarsitektur: Salahsatu hasil observasi lapangan di kota Surabaya

Padahal, menurut Mangunwijaya (2009), berarsitektur, berarti berbahasa dengan ruang dan gatra, dengan garis dan bidang, dengan bahan material dan suasana tempat. Berarsitektur adalah berbahasa manusiawi dengan citra unsur- 
unsurnya, baik dengan bahan material maupun dengan bentuk dan komposisinya. Artinya, interaksi dan komunikasi dengan seluruh unsur arsitektural, baik bentuk, fungsi, struktur, material, dan suasana yang tercipta, adalah kebutuhan niscaya bagi mahasiswa arsitektur.

Jika pada tingkat pengalaman berarsitektur masih tergolong cukup tinggi, pada tingkat kreativitas desain mahasiswa justru lebih rendah lagi. Hasil penelitian menunjukkan bahwa kreativitas desain arsitektur mahasiswa program studi Pendidikan Arsitektur UPI tergolong rendah. Fenomena ini dapat didalami dari dua segi.

Pertama, jika dilihat dari aspek-aspek kreativitas yang diteliti, aspek orisinalitas dan keunikan ide desain memiliki skor sebesar 51,48\% yang merupakan skor tertinggi dibandingkan aspek lainnya, yaitu aspek kepekaan terhadap masalah yang muncul, kecerdikan dalam pemecahan masalah, dan ketepatan pemecahan masalah yang mengandung nilai guna. Hal ini mengindikasikan bahwa potensi mahasiswa program studi Pendidikan Teknik Arsitektur UPI, sesungguhnya memiliki potensi untuk lebih mengembangkan kreativitas desainnya melalui originalitas dan keunikan ide desain pada gambarnya.

Persoalannya, orisinalitas ide saja tidak cukup, seperti disebutkan oleh Alomar (2013), dengan merujuk pada Kinnon, bahwa dalam pengembangan desain arsitektur dan manajemen, kreativitas harus dieksplorasi melalui tiga hal: ide harus dikembangkan dan adaptif terhadap realitas; ide harus mampu menjawab permasalahan dalam berbagai situasi dan dapat diorganisasi untuk mencapai tujuan; ide memiliki keberlanjutan dan dielaborasi untuk dikembangkan secara penuh.

Kedua, misi program studi Pendidikan Arsitektur, memang bukan untuk menghasilkan calon Desainer atau Arsitek. Prodi ini diselenggarakan untuk menghasilkan calon Pendidik pada rumpun Teknik Bangunan di SMK dan atau lembaga Diklat Industri. Dengan demikian, secara konsep, kurikulum Pendidikan Arsitektur tidak menekankan pada aspek Perancangan yang menuntut kreativitas desain tinggi. Kurikulum bertujuan mengantarkan mahasiswa untuk memiliki kemampuan membuat, membaca, melaksanakan, dan mengajarkan kembali 
gambar kerja perancangan (detail engineering design) bangunan. Hal itu tidak berarti bahwa kreativitas tidak diperlukan. Justru, kreativitas sebagai pendidik, melebihi sebagai perancang, yang berfokus pada orisinalitas, kepekaan, dan ketepatan dalam pemecahan masalah pembelajaran, tentu sangat dibutuhkan.

Hasil uji hipotesis menyatakan bahwa terdapat hubungan yang positif dan signifikan antara pengalaman berarsitektur mahasiswa dengan kreativitas desain mahasiswa. Hal ini menegaskan bahwa pengalaman berarsitektur mahasiswa, baik melalui pengalaman formal terstruktur maupun informal keseharian, dalam pengertian simplistis, dapat mendorong peningkatan kreativitas mahasiswa dalam menghasilkan desain arsitektur.

Kaitan pengalaman dan kreativitas ini selaras dengan penjelasan Osborn dalam Bergh (1983) bahwa selain bakat dan kondisi psikologis, pengalaman merupakan pengaruh internal pada kreativitas. Lebih lanjut Wilson (1992) menjelaskan bahwa, pengalaman arsitektur dapat membantu seorang arsitek dalam membuat arsitektur, karena sebuah pengalaman estetik menghadirkan langsung esensi dari pengalaman itu sendiri. Pengetahuan dan pemahaman ruang yang didapat dari pengalaman tersebut tidak dapat diperoleh dengan cara lain kecuali mengalami sendiri. Imajinasi arsitektural lebih merupakan imajinasi natural daripada imajinasi artifisial. Imajinasi natural memerlukan proses kontemplatif dari pengalaman pengalaman yang didapatkan, agar dapat menghadirkan kembali dalam bentukan yang lebih baru.

\section{KESIMPULAN}

Hasil penelitian mengenai pengalaman berarsitektur mahasiswa, yang mencakup mengalami, menggunakan, dan memahami, mendeskripsikan bahwa pengalaman berarsitektur mahasiswa Program Studi S1 Pendidikan Teknik Arsitektur UPI berada pada kategori cukup. Sedangkan, kreativitas desain mahasiswa, yang mencakup orisinalitas, kepekaan, kecerdikan, dan ketepatan pemecahan masalah, tergolong kategori rendah.

Selanjutnya, hasil uji hipotesis menunjukkan bahwa hubungan diantara kedua variabel yaitu pengalaman berarsitektur dengan kreativitas desain memiliki korelasi positif dan signifikan. Hal ini juga menggambarkan bahwa semakin 
tinggi pengalaman berarsitektur, maka semakin tinggi pula kreativitas desain mahasiswa. Kontribusi pengalaman berarsitektur mahasiswa terhadap kreativitas desain, sebesar $43,76 \%$. Hal ini menjelaskan bahwa kreativitas desain mahasiswa sebesar $43,76 \%$ turut ditentukan oleh pengalaman berarsitektur mahasiswa, sedangkan, sebesar 56,24\% ditentukan oleh faktor lain yang tidak diteliti dalam penelitian ini.

Berdasarkan hasil penelitian ini, peneliti merekomendasikan beberapa hal. Pertama, dalam memperdalam dan meningkatkan keilmuan pendidikan arsitektur, mahasiswa hendaknya tidak hanya terbelenggu pada pembelajaran dalam perkuliahan formal saja. Pengembangan ilmu pengetahuan juga harus diiringi dengan pengalaman praktis dan praksis berasitektur di luar perkuliahan. Kedua, kurikulum program studi Pendidikan Arsitektur, meskipun tidak untuk menghasilkan lulusan calon Arsitek, tetapi tetap harus lebih memberi bobot pada peningkatan kreativitas desain. Kurikulum bertujuan mengantarkan mahasiswa untuk memiliki kemampuan membuat, membaca, melaksanakan, dan mengajarkan kembali gambar kerja perancangan (detail engineering design) bangunan. Hal itu tidak berarti bahwa kreativitas tidak diperlukan. Justru, kreativitas sebagai pendidik, melebihi sebagai perancang, yang berfokus pada orisinalitas, kepekaan, dan ketepatan dalam pemecahan masalah pembelajaran, tentu sangat dibutuhkan. Melalui proses pembelajaran Studio Arsitektur, peningkatan kreativitas desain arsitektur diharapkan memiliki implikasi pula bagi pengembangan kreativitas calon Pendidik secara umum. Topik ini, juga barangkali dapat menjadi bahan penelitian selanjutnya bagi para peneliti lain.

\section{DAFTAR PUSTAKA}

Alomar, M.A. 2013. Creativity in Architecture and Management. $6^{\text {th }}$ ADC.

Andresen, L., Boud, D., and Cohen, R. 1993. Experience Based Learning. Chapter published in G. Foley (Ed.). Understanding Adult Education and Training. Second Edition. Sydney: Allen \& Unwin, 225-239.

Antoniades, A.C., 1992. Poetics of Architecture: Theory of Design, , New York: Van Nostrand Reinhold.

Bhat, Vasant D. (2004/2012). Experiental Learning: A Handout for Teacher Educators. Regional Institute of Education, Mysore

Broadbent, G. 1973. Design in Architecture: Architecture and the Human Sciences, John Wiley \& Sons Ltd. 
Holzer, M.S. and Andruet, RH. 2000. Active Learning in Classroom. Proceedings, ASEE Southeastern Section Annual Meeting, Roanoke,VA, April 2-4, 2000

Klassen, W. W. (1990). Architecture and philosophy: phenomenology, hermeneutics, deconstruction. University of San Carlos.

Kowaltowski , DCKK., Bianchi, G., Paiva, FT., (2010). Methods that may stimulate creativity and their use in architectural design education. Published online: 13 November 2009. _ Springer Science+Business Media B.V.

Koberg, Don. 1995. The All New Universal Traveller. : A Guide To Creativity, Problem Solving.\& The Process Of Reaching Goals. Crips Publication

Mangunwijaya. 2009. Wastu Citra. Jakarta : Gramedia.

O'Gorman, James F. (1998) ABC of architecture. Pennsylvania: University of Pennsylvania Press.

Salura, Purnama. 2001. Ber-Arsitektur : Membuat, menggunakan, mengalami, dan memahami arstektur. Bandung : Architecture \& Communication. 